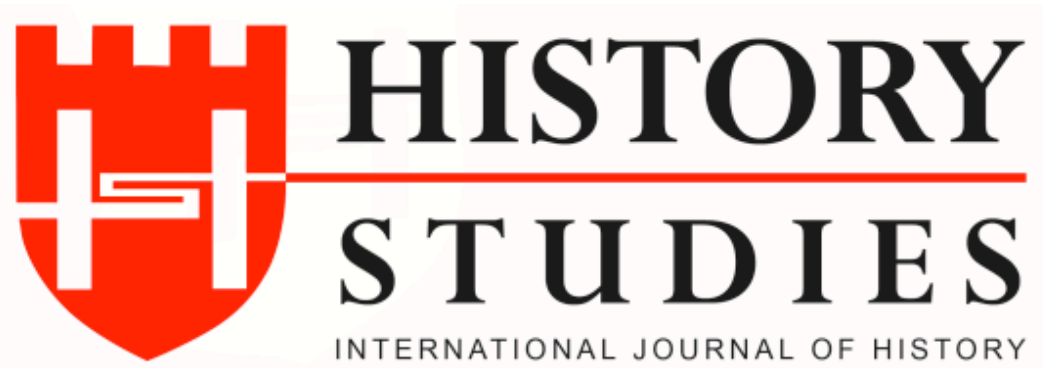

ISSN: 13094173 (Online) 1309 - 4688 (Print)

Volume 9 Issue 3, September 2017, p. 111-120

DOI: $10.9737 /$ hist.2017.544

\title{
Mehmed Esad Safvet Paşa'nın Devair Müfettişliği Sırasında Muhacirler ve Muhacir Çocuklarıyla İlgili Görüşleri ve Bu Konudaki Çalışmaları*
}

The Opinions of Mehmed Esad Safvet Pasha Regardin Refugee Children and His Studies Related to It during His Office of Devair Inspection

\author{
Yrd. Doç. Dr. Pelin İSKENDER KILIÇ \\ (ORCID: 0000-0001-8755-5989) \\ Ondokuz Mayls Üniversitesi - Samsun
}

\begin{abstract}
Öz: Mehmed Esad Safvet Paşa, Osmanlı Devleti'nin son döneminin önemli bürokratlarından biridir. 1831 tarihinde girmiş olduğu devlet memuriyetine aralıksı 1883 yılına kadar devam etmiştir. Diplomat olması nedeniyle devletin karşı karşıya kaldığı tüm sorunlarda aktif görev almış, önemli anlaşma ve toplantılada etkin olarak devletin siyasetine yön vermeye çalışmıştır. Bulunduğu görevler gereği, Tanzimat Fermanı ile başlayan batılaşma yönündeki çalışmalarda yer almıştır. Memuriyetinin son üç yılında Devair Müfettişliği yapmış ve bu görevi esnasında devletin karşı karşıya kaldığı bir çok problem hakkında tecrübelerinden de yararlanarak raporlar hazırlamış, padişaha layiha sunmuş ve çözüm üretmeye çalıșmıștır. Dönemin en önemli problemlerinden birisi de yoğun olarak devletin politikasını etkileyen Balkanlardaki sorunlar ve muhacir meselesidir. Özellikle göçler esnasında en büyük sıkıntıyı çeken muhacir çocuklarının durumu ve onların eğitimi ile yakından ilgilenmiştir. Bu makalede Mehmed Esad Safvet Paşa'nın bu konuya yaklaşımı ve ürettiği çözüm önerileri ortaya konulmaya çalışılmıştır.
\end{abstract}

Anahtar Kelimeler: Mehmed Esad Safvet Paşa, Muhacir, Muhacir Çocuklar, Balkanlar

Abstract: Mehmed Esad Safvet Pasha was one of the most important bureaucrats in last period of Ottoman State. He continued his state civil service which he started in 1831 uninterruptedly until the year of 1883. Since he was a diploat he played an active role in all the problems the state had faced and tried to steer the politics of state by attending important agreements and meetings efficiently. He took part in the westernization reforms that began with Tanzimat Reform because of the positions he occupied. He worked as a devair inspector in last three years of his civil service and during this post, he wrote many reports about many problems that the satate had encountered, submitted "layiha" to the Sultan and tried to produce some solutions by means of using his experiences. One of the major problerms of this period is the issues in Balkans and the refugee problems that deeply affect the politics of the Empire. Esspecially he showed great interst in the condition and the education of refugee children who mostly suffered from these migrations. In this paper, it is tried to reveal the approach of Mehmed Esad Safvet Pasha to this issue and the solutions he produced for it.

Keywords: Mehmed Esad Safvet Pasha, Refugee, Refuge Children, Balkans.

\section{Giriş}

1814'te İstanbul'un Fatih semtindeki Haydar Mahallesi'nde doğan Medmed Esad Safvet Paşa, tahsiline ilk olarak mahalle mektebinde başlamış daha sonra Beyazıt Camii'nde medrese

*Bu makale Mehmed Esad Safvet Paşa (1814-1883 / H. 1230-1301), başlıklı (Ondokuz Mayıs Üniversitesi Sosyal Bilimler Enstitüsü Tarih Anabilim Dalı, Samsun 1999) Yayımlanmamış DoktoraTezinden üretilmiştir. 
derslerine devam etmiştir. Arapça, Farsça ve Bâb-1 âlî Tercüme Odasında Fransızca öğrenmiştir. 1831'de kaydedildiği ve iki sene maaşsız çalıştığı Divân-1 Hümâyûn Kalemi'nde Safvet mahlasını almıştır. İlk memuriyetine 1833'te Bâb-1 âlî Tercüme Odası'nda başlamıştır. Buraya ilk gelenlerden olan Safvet Paşa Âli, Fuat ve Vefik Paşalarla birlikte Tanzimat Devri'nin ünlü Hariciye nazırı, sadrazam ve reformcu grubun önde gelen liderlerinden biri olmuştur. Daha sonra sırasıyla Divân-1 Hümâyûn Mütercim-i evvelliğine, Divân-1 Hümâyûn Tercümanlığı vekâletine ve Takvim-i Vekâyi Nezaretine atanmıştır. 1845'te Hariciye kâtibi olmuş, aynı yıl Sultan Abdülmecid tarafından ulâ sınıf-1 sanisi rütbesiyle Mabeyn-i Hümayun Dördüncü Kitâbeti'ne ve Fransızca öğretmesi için kızı Fatma Sultan ile oğlu Murat Efendi'nin hocalığına tayin edilmiştir. 1855 'te Hariciye Nezareti müsteşarlığına daha sonra da Hariciye Nezareti vekâletine getirilmiştir. Mehmed Esad Safvet Paşa, 1855 'den itibaren sırasıyla Meclis-i Âlî Tanzimat azalığı, Sadaret müsteşarlığı, Meclis-i Vâlâ azalığı ve reisliği, Şûrâ-yı Devlet azalığ 1 ve reisliğinde bulunmuştur.

Tanzimat Devri'nin önemli devlet adamlarından biri olan Mehmed Esad Safvet Paşa, bir diplomat olarak yetiştirilmiştir. Yukarıda belirtildiği gibi devletin hemen hemen her kademesinde çalıştıktan sonra çeşitli nazırlıklara getirilmiştir. Üç kez Ticaret Nazırlığı, üç kez Maarif Nazırlığı, Adliye Nazırlığı, Nafia Nazırlığı ve iki günlük son Hariciye Nazırlığı hariç beş kez Hariciye Nazırlı̆̆ı, altı ay gibi kısa bir süre de sadrazamlık yapmıştır. Bu görevleri esnasında Osmanlı Devleti için son derece önemli olan Tersane Konferansı, Kıbrıs Antlaşması, Berlin Antlaşması'nda etkili görevler üstlenmiştir. Bunların içinde üç kez getirildiği ve önemli gelişme ve yeniliklerin gerçekleştirildiği Maarif Nazırlıkları son derece önemlidir. İlk Maarif Nazırlığı döneminde Galatasaray Mekteb-i Sultanisi ve Darülmuallimat açılmış, Maarif-i Umumiye Nizamnamesi hazırlanmış, Darülfünun yeniden açılmıştır. Ayrıca Safvet Paşa, iki kez Paris sefirliğine atanmıştır. Paris sefirliğinde bulunması ve bu dönemin genel politikası gereğince Fransa'nın etkisinde kalmıştır.

Abdülaziz ve II. Abdülhamid'in saltanatının ilk on yılı içinde devletin iç ve dış siyasi hayatında ileri görüşü, dürüst karakteri ve otoritesiyle tanınmış olan Medmed Esad Safvet Paşa, beşinci kez getirildiği Hariciye Nezareti'nde iki ay yirmi dört gün kaldıktan sonra 19 Ekim 1879'da 39.000 kuruş maaşla Umûm Devâir Müfettişliği'ne getirilmiştir. ${ }^{1}$ Devlet dairelerinin en yükseği ve en mühimi olan sadaret dairesinden başlayarak belediye dairelerinin tanzifat (temizlik işleri) ve tenvirat (aydınlatma) kalemlerine varıncaya kadar teftiş yetkisi olan Umûm Devâir Müfettişi, oldukça önemli ve zor bir görevi yerine getirmektedir. ${ }^{2}$ Böyle önemli bir göreve doğru tahkikatı, sadakat ve güvenirliliği ile itimat kazanmış bir kişinin getirilmesi gerekmektedir. Bu nedenle her zaman kendini dinî ve vatanî hizmetlere adamış olan Safvet Paşa, bu göreve uygun görülmüştür. ${ }^{3}$ Bu görevi yerine getirebilmek için uzun süre o işin içinde olmak ve olanları iyi tetkik etmek son derece mühimdir ve Safvet Paşa'nın devletin çeşitli kurumlarında çalışmış olması ve bundan kaynaklı bilgi birikimi oldukça önemlidir. ${ }^{4}$ Medmed Esad Safvet Paşa, göreve başladığında maiyetinde her sınıftan teftiş heyeti, kâtipler ve gizli memurlar vardı. Onların vasıtasıyla devlet dairelerinde vasat işlerin nasıl yürütüldüğüne dair bilgi sahibi olup, yolsuz bir şey gördüğü takdirde bunun 1slah edilmesi yoluna giderek, bunları daima teftiş altında bulundurup, önemli konularla ilgili zaman zaman Padişaha bilgi veriyordu. $^{5}$

\footnotetext{
${ }^{1}$ BOA, İdare-i Dahiliye No: 64421. 17 Ekim 1879 (3 Zilhicce 1296) tarihli yazı.

${ }^{2}$ BOA, YEE 78 / 47. 16 Ocak 1881 (15 Safer 1298) tarihli Safvet Paşa’ya Başvekâletten yazılan tezkere.

${ }^{3}$ BOA, YEE $78 / 47$.

4 İbnü'l-Emin Mahmud Kemal İnal, Osmanlı Devrinde Son Sadrazamlar, Cilt: VI, s. 866.

5 BOA, YEE 78/ 48. 18 Ocak 1881 (17 Safer 1298) tarihli Safvet Paşa'nın, irade mucebince dairelerin işleyişi hakkında layihalar vereceğine dair tezkere.
} 
Medmed Esad Safvet Paşa, Umûm Devâir Müfettişliği’nde, 30 Kasım 1882 tarihine kadar üç seneden fazla kaldı. Bu sırada birçok daireyi teftiş etti ve bazı konularla ilgili görüşlerini belirten raporlar hazırladı. Bu raporlardan bazıları şu konularla ilgilidir: Devletin mali işlerinin ıslahı; Mahsulattan alınmakta olan Öşür Resmi; Osmanlı Devleti'nde baş gösteren kıtlığa karşı alınması gereken tedbirler; Osmanlı Devleti'nin gelirlerinin artmasında ulaşımın yeri ve önemi; Osmanlı Ülkesi’nin zıraat, maden vs. servetlerinin keşif, tayin ve tespiti, Mahalli sanayinin ilerlemesi için alınacak tedbirler; Osmanlı Devleti'ne dışarıdan ithal edilen malların rüsumu; Osmanlı Devleti'nde imar faaliyetleri; Tuna Nehri'nde gemi işletmeciliği; Dicle ve Firat Nehirleri üzerinde seyr-i sefain; Tunus, Trablusgarb ve Misır'ın durumu; Rumeli'de Osmanlı Devleti'nin elinde kalacak vilayetlerin idaresi; Berlin Kongresi gereğince oluşturulan 1slahat komisyonu vb. Bu konulardan biri de Berlin Muahedesi sonucu muhacirlerin ve muhacir çocukların durumudur.

\section{Berlin Muahedesi Sonucu Muhacirlerin Durumu}

Osmanlı Devleti ile Rusya arasinda meydana gelen 93 Harbi'nin sonucu, Osmanlı Devleti'nin Paris Muahedesi ile temin olunan topraklarının bütünlüğü ilkesi ihlal edilmiş, Osmanlı Devleti'nin varlık ve devamlılı̆g zamanın gereklerine ve devletlerarasındaki politikalara bağlı muallak bir hale gelmişti. Rumeli Bölgesi'nin en önemli noktasında bir Bulgar Emareti kurulmuştu. Bundan dolayı Osmanlı Devleti'nin Rumeli'deki durumu oldukça önem kazandı. Rumeli'de doğrudan doğruya Osmanlı Devleti'nin idaresi altında bulunan yerler Selanik, Yanya, Manastır, İşkodra, Kosova ve Edirne vilayetleri idi. Bu dönemde Rumeli, bozgunculuk ve tahriklerle devamlı karışıklık içindeydi. ${ }^{6}$

1877-1878 Osmanlı-Rus Savaşı'nın başlaması ile birlikte Rus ordusunun Balkanlar'da ilerlemesi ve istilâsı üzerine birçok Müslüman, Anadolu'ya doğru göçe başlamış, savaş süresi ve sonucunda göç hareketi artarak devam etmişti. Bu göçler Arnavutluk, Bosna-Hersek, Bulgaristan, Karadağ $\breve{g}^{7}$, Kosova, Makedonya ve Yunanistan'dan yani Balkanların hemen her yerinden olmuştur. Mehmed Esad Safvet Paşa, Hariciye Nazırlıkları döneminde Balkan Bölgesi ile ilgili aktif olarak siyasi faaliyetlerde bulunmuştur. Ancak Devair Müfettişliği sırasında daha çok Bulgaristan'dan gelen göçler ve muhacirlerle ilgili rapor hazırlamıştır.

Bulgaristan'dan olan göçlerde, Rusların ele geçirdiği yerlerdeki Müslümanları göç ettirmek için başvurduğu zulümlerin yanı sıra yerli Bulgar halkın silahlanıp Rumeli’nin yerli Müslüman halkını yok etme veya kovma isteği ile yaptığı zulümlerin de rolü büyüktü. ${ }^{8} 4$ Ağustos 1879 tarihinde Safvet Paşa, Paris Maslahatgüzarı Nikolaki Efendi'ye yolladığı bir yazısında Müslümanların Bulgarlardan son derece kötü muamele gördükleri ve durumlarının iyi olmadığı hakkında bilgilendirmede bulundu. ${ }^{9}$ Şarkî Rumeli ahalisinin yarısından fazlası memleketlerine döndükleri halde bunlara ait araziler, Bulgarlar tarafindan zaptedilmişti. 1879 senesinde Bulgarlar tarafindan alınmış olan hasılattan Türklere ait olan akçeler hükümet sandığında saklanarak verilmedi. Verilmesi halinde Müslüman halk, tohum ve çiftlik edevatı tedarik ederek, biraz olsun rahatlayacaktı. Bu konuda Bulgar Devleti, Müslüman ahaliye gelirlerini ve arazilerini geri vermede büyük zorluklar çıkartıyordu. ${ }^{10}$

\footnotetext{
${ }^{6}$ BOA, YEE 44 / 132. 4 Aralık 1879 (20 Zilhicce 1296) tarihli Safvet Paşa'nın yazısı.

${ }^{7}$ Bkz. Abidin Temizer, "Karadağ'da Öteki Sorunu: Müslümanlar (1878-1913)”, History Studies, Volume 5, İssue 3, Mayis 2013, s. 223-240.

8 Faruk Kocacık, "Balkanlar'dan Anadolu'ya Yönelik Göçler (1878-1890)", Osmanlı Araştırmaları, Sayı:1, İstanbul 1980, s. 140.

${ }^{9}$ N. Bilal Şimşir, Rumeli'den Türk Göçleri, Cilt: II, Ankara 1989, s. 421.

${ }^{10}$ BOA, YEE 44 / 128. Safvet Paşa'nın tezkeresi. Bkz. Nedim İpek, Rumeli'den Anadolu'ya Türk Göçleri (18771890), Ankara 1994, s. 32.
} 
Safvet Paşa, 16 Ekim 1879 'da İstanbul'daki Bulgar ajansına, Bulgaristan'da Müslümanlara yapılan sistematik zulümlerden, Türklerin dükkânlarına, okullarına, camilerine ve türbelerine yapılan saldırılar ile yaralama ve öldürmelerden bahsetti. Daha sonra bu konu ile ilgili Bulgaristan'a bir de nota verildi. Bu nota üzerine Bulgar Prensliği, bu duruma son verecek tedbirlerin alınacağına dair Bâb-1 âlı̂’ye güvence verdi. ${ }^{11}$ Burada Safvet Paşa'nın amac1, Bulgaristan Türklerini göçten vazgeçirerek, bu bölgede bir Türk kitlesinin kalmasını sağlamaktı. Safvet Paşa, Osmanlı Devleti’nin devamlılığını Rumeli Bölgesi’ni idaresi altında bulundurmasına bağlı görüyordu. Bundan dolayı buradaki Türk nüfusunun korunarak göçettirilmemesi politikasını güdüyordu. Hatta bu doğrultuda Şubat 1878'de başlayan Osmanl1-Rus barış müzakerelerinde Osmanlı delegesi olan Safvet Paşa, bir nüfus değiş tokuşu düşüncesini ortaya attı. Balkan sıra dağlarının kuzeyinde kalan Türkleri güneye, sıra dağların güneyinde kalan Bulgarları da kuzeye göndermeyi ve bu Türklerle Bulgarların mal ve mülklerinin karş1lıklı olarak tasfiye edilmesini teklif etti. Yüzbinlerce insanın yerinden sökülüp başka yerlere kaydırılması demek olan böyle bir nüfus mübadelesi pek kolay bir iş değildi. Rus delegeleri, Safvet Paşa'nın bu teklifini reddettiler. Türkleri fiilen göçe zorlamak varken hukukî yoldan değiş-tokuş etmek Slav milliyetçilerinin işine gelmedi. ${ }^{12}$

Safvet Paşa'ya göre Rumeli'de Türk sınırı dahilinde kalan yerlerde asayişin sağlanması iki şarta bağlıydı: 1. Mevcut kanun ve nizamların tam anlamıyla uygulanarak, bir isyan belirtisi ve ihtilal görüldüğünde oraya derhal bir askeri kuvvet sevk edilerek, bölgede yüz yirmi bin sinırında kuvvet bulundurmak, 2. Osmanlı Devleti'nin içinde bulunduğu durum ekonomik ve askeri yönden zayıf olduğundan, bölgenin adaletle idare edilmesi idi. ${ }^{13}$

Bütün çabalara ve müzakerelere rağmen göç eden Türk nüfus her geçen gün daha da artıyordu. Gerek Rumeli'de kalan gerekse İstanbul'a gelen muhacirlerin durumu hiç iyi değildi. İstanbul'da bulunan, Rumeli'ye gidenlerden geri dönen veya Anadolu'nun çeşitli yerlerine iskân edilenlerden memleketlerine geri dönmek niyetiyle gelen muhacirler, oldukça perişan ve sefalet içinde bulunmaktaydılar. Bunlara devletin yardımı, içinde bulunulan şartlar nedeniyle istenilen ölçüde değildi. Yerli halkın durumu da iyi olmadığ yardımda bulunabiliyorlardı.

Muharebeden önce İstanbul'da Rumeli ahalisinden dilenen bir kişiyi görmek mümkün değil iken hatta Safvet Paşa'nın deyimi ile bayağı dairelerde hizmetkârlık edenler bile çok az iken muharebeden sonra muhacirlerden birçok kadın ve kız sokaklarda dilenmekteydi. Bunların içinde bulunduğu bu kötü durum, çoğu kişiyi endişelendiriyordu. Osmanlı hükümeti, muhacirlerle ilgilenmek için bir encümen oluşturdu. Ancak Safvet Paşa'ya göre bunun başında bulunan kişi iyi vasıflara sahip ve gayretli ise de gerek yaş gerekse vücut bakımından bu gibi ağır işlerle uğraşmaya uygun değildi. Bu nedenle idare komisyonuna birkaç kişi daha ilave edilerek, başkanlığına da genç, gayretli, devamlı muhacirlerin durumlarını iyileştirmek ve gerekli yardımların yapılmasını sağlamak amacıyla çalışan bir kişinin tayin edilmesi gerekiyordu. Safvet Paşa, bu iş için eski Bosna valisi Muzaffer Paşa'yı uygun bulmaktaydı. ${ }^{14}$ Bu muhacir akını karşısında muhacirlerin problemleriyle ilgilenmek üzere bu dönemde birçok komisyon ve bunlara bağlı şubeler oluşturuldu. Her komisyon muhacirlerin ayrı bir sorunu ile ilgilenmekteydi. $^{15}$

\footnotetext{
${ }^{11}$ N. Bilal Şimşir, a.g.e., Cilt: II, s. 540.

${ }^{12}$ N. Bilal Şimşir, "Bulgaristan Türkleri ve Göç Sorunu", Bulgaristan'da Türk Varlığı-I, Ankara 1987, s. 47-66.

${ }^{13}$ BOA, YEE 44 / 1324 Aralık 1879 (20 Zilhicce 1296) tarihli Safvet Paşa'nın yazısı.

${ }^{14}$ BOA, YEE 44 / 124. 23 Ocak 1880 (10 Safer 1297) tarihli Safvet Paşa'nın yazısı.

${ }^{15}$ Nedim İpek, Rumeli'den Anadolu'ya Türk Göçleri (1877-1890), Ankara 1994, s. 68-74.
} 
Anadolu'ya gönderilen ve Trabzon taraflarında bulunan muhacirlerin durumları da bunlardan farklı değildi. Onların da her geçen gün perişanlığı ve kötü şartlar nedeniyle ölenlerin sayısı giderek artmaktaydı. Bundan dolayı göçmenlerin ne kadarının kesin olarak yerleştirilip ne kadarının misafir halde bulunduğunun bir an önce tespit edilmesi gerekiyordu. ${ }^{16}$

Güvenilir bir kaynağa göre İstanbul' da bulunan muhacirlerin sayısı kadın ve erkek toplam 60.000 kadardı. 1879'da Bulgaristan ve Doğu Rumeli'ye sevkedilen veya kendiliğinden giden muhacirlerden evleri yıkılmış, ziraat için gerekli olan çiftlik hayvanları, tohum ve aletleri kaybolmuş olanların bahar mevsiminde İstanbul'a gelecekleri haber alınmıştı. ${ }^{17} \mathrm{Bu}$ muhacirlerin yerlerinde kalması, evlerini inşa edip hayvan ve tohum satın alabilmeleri için yeterli miktarda para gerekiyordu. Fakat Osmanlı hazinesi, isyanlar ve savaşlar nedeniyle buna müsait değildi. Bu nedenle muhacirlerin kullandıkları arazinin rehine verilmesiyle, kendilerine borç para verecek bir bankanın kurulması gerekmekteydi. Mülk sahibi bazı muhacirlerin rica ve iltimasları üzerine böyle bir bankanın kurulmasını uygun bulan İngiliz Hanson tarafından teklif edilen şartların bazıları ağır bulundu. 200.000'i aşan nüfus bir an önce yerleştirilmezse perişan ve sefalet içinde kalacaklardı. Aksi takdirde kadın ve çocuklar çok yıpranmış olduklarından yarıdan fazlası telef olacaktı. ${ }^{18}$ Safvet Paşa, bu konu ile ilgili İngiliz büyükelçisi Layard ile görüşmüş ve Edirne'de bulunan 80.000 göçmenin 1879 kış aylarında açlıktan kırılma tehlikesi içinde olduğunu, bunlara yardım sağlamak için Osmanlı Bankası'ndan kredi alma düşüncesinde bulunulduğunu söyleyerek, bankanın kredi vermeyi reddetme ihtimali üzerinde durmuştur. ${ }^{19}$

HISTORY STUDIES 115

Volume 9 Issue 3 September 2017

2. Rumeli Muhacirlerinden Taşraya Gidemeyip, İstanbul'da Kalan Yetim ve Öksüz Çocukların Tahsili

19. yüzyıla kadar Osmanlı Devleti'nde özellikle sosyal hizmetler anlamında vakıflar son derece etkiliydi. Bu yüzyıla kadar yetim ve öksüz çocukların bakımı ile daha çok yakın aile fertleri ilgilenmiş ve ilgili vakıflar tarafından da onların yiyecek, giyecek gibi bir takım ihtiyaçları karşılanmaya çalışılmıştır. Fakir ve yetim çocuklara günde iki defa yemek verilmesi ve bayramlar başta olmak üzere yılın belli zamanlarında giyecek yardımında bulunulması bu hizmetler arasındaydı ${ }^{20}{ }^{20}$. yüzyıla gelindiğinde vakıflar, sosyal yardım işlevlerini yavaş yavaş yitirmeye başlamış, devlet sistemindeki merkezileşme ile birlikte devlet, sosyal hayatın birçok alanında nüfuzunu arttırmıştı. Daha önceden devletin görevleri arasında yer almayan ya da sınırlı ilişkisi olan pek çok alan, zamanla devletin sorumluluk alanı içine girdi. Bu alanlardan biri de yetim, öksüz ve fakir çocukların durumu ile onların eğitimi meselesidir. Bilhassa bu yüzyılda savaşlar nedeniyle meydana gelen göçler sonucu göçmenlerin barınma, beslenme, sağlık vb. problemlerinin yanı sıra eğitim problemleri de vardı.

Tanzimatla bereber batılılışmanın da etkisiyle eğitim, sosyal devletin bir gereği olarak daha farklı bir boyut kazanmıştır. Üç kez Maarif Nazırlığına getirilmiş olan Mehmed Esad Safvet Paşa'nın birçok yeniliklerin yapıldığı I. Maarif Nazırlı̆̆ dönemi bu anlamda oldukça önemlidir. Bu dönemde eğitimde kargaşaya son verilerek, eğitimin devlet eliyle yapılması gereği üzerinde durulmuş ve bu alanda bir düzenin sağlanması amaçlanmıştır. Safvet Paşa, devletin temel görevlerinden birisinin de kamu eğitimini gerçekleştirmek olduğunu savunanlardandır. Bu doğrultuda Fransa'daki eğitim hareketleri incelendikten sonra onun da

\footnotetext{
${ }^{16}$ BOA, YEE 44 / 124; Bkz. Nedim İpek, Rumeli'den Anadolu'ya Türk Göçleri (1877-1890), Ankara 1994.

${ }^{17}$ BOA, YEE 44 / 127. Safvet Paşa'nın tezkeresi.

${ }^{18}$ BOA, YEE 44 / 127. Safvet Paşa'nın 23 Ocak 1880 (10 Safer 1297) tarihli yazısı.

${ }^{19}$ N. Bilal Şimşir, a.g.e, Cilt: II, s. 427.

20 Yahya Araz, 16. Yüzyıldan 19. Yüzyıl Başlarına Osmanlı Toplumunda Çocuk Olmak, Kitap Yayınevi, İstanbul 2013, s. 112-113.
} 
katkılarıyla bir kurul tarafından 1869'da Maarif-i Umumiye Nizamnamesi hazırlanmıştır. 198 maddeden meydana gelen nizamnamede birçok konuya değinilmiştir. ${ }^{21}$ Maarifin gelir kaynakları olarak da devlet bütçesinden ayrılan para, halkın vereceği yardımlar, vakıf gelirlerinden alınacak para, diğer yardımlar, lise ve yüksekokul talebelerinden alınacak ücret ve para cezaları gösterilmiştir. ${ }^{22}$

Osmanlı Devleti'nin modernleşme ve sosyal devlet olma çabası içinde bulunduğu bu dönemde, üretme kapasitesi olan fakat devlet ve toplum tarafindan kaygı duyulan ve ekonomik yük olarak görülen kent yoksulları (dilenciler, serseriler, fakirler, öksüz ve yetim çocuklar) ve bunların üretime sokulma çabaları önemliydi. Bu da ancak eğitimle sağlanabilirdi. Özellikle ileride problem olmaması için yetim, öksüz ve göçler sonucu gelen fakir muhacir çocuklarının eğitilerek bir meslek sahibi yapılmaları büyük önem taşımaktaydı. ${ }^{23} \mathrm{Bu}$ amaçla Tanzimat döneminde bu çocukların eğitimlerine önem verilerek, bir takım kurumlar açılmıştır. II. Abdülhamid döneminde öksüz ve yetim Müslüman çocukları okutmak için Cemiyyet-i Tedrisiyye-i İslamiyye tarafından 1873 'te İstanbul'da açılan Dârüşşafaka bunlardan biridir. ${ }^{24}$ 1877-1878 Osmanlı - Rus Savaşı'nın patlak vermesi Dârüşşafaka'yı da etkilemiştir. İstanbul'da toplanan Rumeli göçmenlerinin bir kısmı bu okula yerleştirildiği için altı ay kadar ders yapılamamıştır. Çoğu subay olan öğretmenler, cepheye gittiğinden altıncı sınıf öğrencileri bir yıl ders görememişlerdir. Öğrencilere bile zor yeten okulun gelirleri, göçmenlere harcandığı için maddî sıkıntı had safhaya ulaşmıştır. Nihayet muhacirlere yer bulunarak Dârüşşafaka eski haline kavuşturulmaya çalışılmıştır. ${ }^{25}$ Darüşşafaka'nın diğer önemli bir özelliği de Osmanlı Devleti'nde telgrafçılığın gelişmesinde oynadığı roldür. 1880'li yıllarda telgrafçıları, en gelişmiş liseler olan Galatasaray ve Darüşşafaka' da yetiştirmek fikri ortaya atılmıştır. Galatasaray'ın elit kökenli öğrencileri telgraf memuru olmayınca Darüşşafaka'ya elektrik dersi konularak, okul Telgraf Fen Mektebi haline getirilmiştir. Bu nedenle matematik ve fizik eğitimi güçlendirilmiş ve ünlü kişiler yetişmiştir. ${ }^{26}$

Fakir ve kimsesiz çocuklar için yalnızca başkentte değil Osmanlı topraklarının farklı birçok yerinde çeşitli kurumlar açılmış, II. Abdülhamid döneminde bunlar yaşatılmaya ve yenileri açılarak geliştirilmeye çalışılmıştır. Ocak 1876 'da Manastır vilayetinde islahhane açmak için teşebbüste bulunulmuş ve hayırseverlerden de destek alınmıştır. Ancak çeşitli nedenlerle bu girişim hemen sonuç vermemiş, 1889 yılı ortalarında Manastır'daki fakir çocukların eğitimi için vilayet merkezinde, nizamiye karakolunun karşısında askeriyeye ait olup kullanılmayan 6 dönüm, 250 arşınlık bir alanda ıslahhane açılması çalışmaları başlatılmıştır. ${ }^{27}$

1877-78 Osmanl1-Rus Savaşı'nda alınan yenilgi ve sonrasında yaşanan göçler esnasında en çok sıkıntı çeken ve ölüm oranı en fazla olanlar kadın ve çocuklardır. Birçok çocuk savaşlar ve göçler sırasında ölmüş, yetim kalmış veya Bulgarlar tarafından alıkonulmuştur. Hariciye

\footnotetext{
${ }^{21}$ Bkz. Pelin İskender, Mehmed Esad Safvet Paşa (1814-1883 / H. 1230-1301), Ondokuz Mayıs Üniversitesi Sosyal Bilimler Enstitüsü Tarih Anabilim Dalı, Yayımlanmamış DoktoraTezi, Samsun 1999, s. 58-70.

${ }_{22}^{2}$ Bayram Kodaman, Abdülhamid Devri Eğitim Sistemi, TTK Basımevi, Ankara 1991, s. 157.

${ }^{23}$ Nadir Özbek, Osmanlı İmparatorluğu'nda Sosyal Devlet Siyaset, İktidar ve Meşruiyet, 1876-1914, İletişim Yayınlar1, İstanbul 2013, s. 65-91.

24 Nurdan Şafak, "Osmanlı İmparatorluğu'da Kimsesiz Çocuk Olmak ve Islahhaneler (1863-1903)”, Osmanlı Dünyasında Çocuk Olmak, Ed. Haşim Şahin-Nurdan Şafak, Dem Yayınları, İstanbul 2012, s. 137.

${ }^{25}$ Halis Ayhan - Hakkı Maviş, "Darüşşafaka”, Türkiye Diyanet Vakfi İslam Ansiklopedisi, Cilt: IX, İstanbul 1994, s. 8.

${ }^{26}$ İlhan Tekeli, “Tanzimat'tan Cumhuriyet'e Eğitim Sistemindeki Değişmeler”, Tanzimat'tan Cumhuriyet'e Türkiye Ansiklopedisi, İletişim Yayınları, Cilt: II, İstanbul 1985, s. 469.

${ }^{27}$ Mucize Ünlü, "II. Abdülhamid Döneminde Balkanlarda Fakir ve Kimsesiz Cocuklar”, Geçmişten Günümüze Şehir ve Çocuk, Editör: Osman Köse, Canik Belediyesi Kültür Yayınları, Samsun 2016, s. 811-812.
} 
Nezaretinden 16 Ekim 1879'da İstanbul Bulgar Ajansı'na bir nota gönderilerek, Vidin Belediye sandığı ile Menafî ve Yetim sandıklarında öksüz göçmenlere ait hisselerin ve ayrıca 20.000 kuruş tutarında bir diğer paranın Türk delegesi İbrahim Hulusi Efendi’ye teslim edilmesi istenmiştir. ${ }^{28}$ Osmanlı Devleti, gelen göçmenlerin eğitimleri konusundaki ihtiyaçlarını karşılamak ve bu konuda yapılabilecekleri imkânları ölçüsünde yapmaya çalışmıştır. Bunun için devletin maarif bütçesine para ayrılmakta ve bu paranın göçmenlerin eğitimi konusundaki istekleri için harcanması sağlanmaktaydı. ${ }^{29}$ Savaşın, isyanların ve göçlerin beraberinde getirdiği birçok sorunun yanı sıra ekonomik bunalım da hat safhadaydı. Buna bağlı olarak en çok kaygı duyulan sosyal sorunlardan biri de dilencilik ve serserilikti. Özellikle 19. yüzyılın sonlarına doğru şehir merkezlerindeki halkın kent yoksullarıyla ilgili taşıdığı kaygılar son derece artmıştı. $\mathrm{Bu}$ yıllara ait gazetelerde dilencilerle ilgili haberler ve kaygılar sıklıkla dile getirilmekteydi. ${ }^{30}$ Bunların içinde Rumeli muhacirleri ve onların yetim kalan çocukları da vardı. Bunlar özellikle İstanbul'da dilencilik yapmaktaydılar. Buna karşı bir önlem almak gerekiyordu. Aksi takdirde böyle yaşamaya alışacak olurlarsa bir zanaat öğrenmek istemeyeceklerdi ve bu durum ileride devlet için problem teşkil edebilirdi. Çünkü tembellik önemli ahlaki sorunları da beraberinde getirmekteydi. Bundan dolayı bu çocukların araştırılıp bulunmaları ve bir meslek edinebilmeleri için sanayi mektebine yerleştirilmeleri Safvet Paşa tarafindan dile getirildi. ${ }^{31}$

Osmanlı Devleti'nde erkek ve kız çocuklarına sanat öğretme işine ilk önce Tuna valisi Mithat Paşa, Rumeli'de başlamıştı. Mithat Paşa'nın bunda amacı hem kimsesiz çocuklara iş bulmak hem memleketin bir kısım küçük sanat ihtiyaçlarını karşılamak hem de orduya lüzumlu olan kumaşları ve kıyafetleri temin etmekti. Yine Rumeli'deki ordunun elbise ihtiyacını temin için bir fabrika kurmuş, Avrupa'ya adamlar göndererek fabrikanın alet ve edevatını getirtmiş ve bu fabrikada çalışmak üzere öksüz kızları toplatıp, 1865 'te $K_{l z}$ Sanayi ektebi açtırmıștır. Istanbul' da ilk sanayi mektebi ise yine Mithat Paşa'nın çabaları sonucu 1868'de Erkek Sanayi Mektebi adıla açılmıştır. Bir yıl sonra da Tophane-i Amire'nin idaresinde bulunan Yedikule'deki fabrikalarda çalışmak ve askere sargı ve çamaşır dikmek ve yetiştirmek üzere bir Kız Sanayi Mektebi açılmıştır. ${ }^{32}$ Bu Safvet Paşa'nın I. Maarif Nazırlığ 1 dönemine rastlamaktadır. Bundan sonraki yıllarda sanayi mekteplerinin kurulmasına devam edilmiştir. 1897 yılında Üsküp'te bir sanayi mektebi açılmıştır. Yine kimsesiz çocukların eğitimi için açılan bu mektebin açılış töreninde padişaha dualar edilmiş, mektebin talebelerin ve törende hazır bulunanların resimleri çekilerek Kosova valisi tarafından merkeze gönderilmiştir. ${ }^{33}$ Sanayi mekteplerinin temelini oluşturan islahhaneler açılmıştır. Bu ıslahhanelere öncelikle 5-13 yaşları arasındaki kimsesiz ve fakir çocuklar alınmıştır. Osmanlılık ideolojisine uygun olarak dil, din ve irk farkı gözetmeksizin herkese açık tutulmuştur. 5 yıllık eğitim süresi olan 1slahhanelerde terzilik, demircilik, kunduracılık, marangozluk, dökmecilik, urgancılık, makinecilik, hasırcılık, ciltçilik vb. meslek kollarında eğitim verilmiştir. ${ }^{34}$

Safvet Paşa'nın düşündüğü yeni kurulacak sanayi mektebi için arazi bulunarak, bir mektep yaptırılsa bile içine ufak bir fabrika inşa edilmesi, alet ve edevatın, öğrenciler için yatak takımlarının ve diğer levazımın tanzim ve tedariki için en az beş-altı yük kuruş

\footnotetext{
${ }^{28}$ N. Bilal Şimşir, a.g.e, C. II, s. 538.

${ }^{29}$ Faruk Kocacik, a.g.m., s. 172.

${ }^{30}$ Nadir Özbek, a.g.e, , s. 79.

${ }^{31}$ BOA, YEE, 44 / 138. 11 Mart 1881 (10 Rebiülahir 1298) tarihli Safvet Paşa'nın yazısı.

${ }^{32}$ Osman Ergin, Türk Maarif Tarihi, C. I-II, İstanbul 1977, s. 686.

${ }^{33}$ Mucize Ünlü, a.g.m., s. 812.

${ }^{34}$ Burcu Kurt, "Modernleşen Sanayiye Ayak Uydurmak: Osmanlı Irak'ında Kurulan Sanayi Mektepleri”, History Studies, Volume 5, Issue 3, Mayıs 2013, s. 154.
} 
gerekmekteydi. Ayrıca öğrencilerin yiyecekleri, giyecekleri ve diğer masrafları da beş yüz kişi üzerinden hesap edildiğinde aylık yetmiş beş- seksen bin kuruşa ulaşacağından bunun miktarı yıllık on iki yük kuruş demekti. Bunun hazineden karşılanması mümkün olmayacağından hazine gelirlerinin bir kaleminden az bir miktarın ayrılmasıyla meydana gelecek miktardan bu masrafların karşılanması mümkün olabilecekti. Bu amaçla emlak idaresinden arazi alımsatımlarında geçici verilen senetlerden alınan dört kuruş verginin altı kuruşa ve daimi olarak verilenlerin onar kuruşa çıkarılması halinde, senelik sarf olunan iki çeşit senedin sayısı altı yüz bin raddesinde olduğundan bu tazminatlardan mektebin masrafları çıktıktan sonra hazineye de fazla para kalacaktı. Bu da Rumeli muhacirlerinin eğitimden mahrum kalan çocuklarının iaşeleri, talim ve terbiyeleri için harcanan masrafları karşılayacaktı. Böylece birkaç yüz fakir ve öksüz çocuğun böyle sokaklarda dilenerek hayat sürmeleri ve okuyup yazmaktan mahrum kalmaları önlenmiş olacaktı. ${ }^{35}$

\section{Sonuc}

Osmanlı Devleti'nin en buhranlı döneminde ve ülkenin iç ve dış siyasetinin en hareketli olduğu zamanlarda son derece önemli mevkilere getirilen Mehmed Esad Safvet Paşa, tam bir diplomat olarak yetiştirilmiştir. Bu konuda kendisine Sadrazam Reşid Paşa yön vermiştir. ${ }^{36}$ Gerek Abdülaziz gerekse II. Abdülhamid dönemlerinde ileri görüşü, dürüst karakteri ve otoritesi ile tanınmıştır. ${ }^{37}$ Bulunmuş olduğu nazırlıklarda yapmış olduğu çalışmalar, yeniliklere açık bir karakteri olduğunu göstermektedir. Bilhassa Maarif ve Hariciye Nazırlıkları ile Devair Müfettişliği sırasında gerçekleştirdiği yenilikler ve ilkler ile ileri sürdüğü fikirler, eğitime ve bilime ne kadar önem verdiğinin ve ülke sorunlarıyla yakından alakadar olduğunun bir göstergesidir.

1879'da tayin edildiği ve 1882 y1lı sonlarına kadar sürdürdüğü Devair Müfettişliği sırasında, devletin en alt kademelerinden başlayarak çeşitli nazırlıkları, Paris sefirliği ve sadrazamlığ da dahil olmak üzere yaklaşık kırk beş yıllık devlet memurluğunun getirdiği tecrübe ile hareket etmiştir. Bilgi birikimi ile aksaklığını gördüğ̈̈ ya da gerçekleşmesinin devletin yararına olacağına inandığı çeşitli konularla ilgili görüşlerini raporlar halinde yazmış, zaman zaman da padișaha layihalar sunmuștur. Hatta bir süre layiha göndermeyince, padișah tarafından uyarılmıştır. Bunun üzerine layiha vermemesinin nedeninin, 7-8 aydan beri önemli meseleler ve dış problemler arasında padişahın daha fazla canının sıkılmasına ve meşguliyete sebep olup rahatsız etmek istemediğinden kaynakladığını ifade etmiştir. ${ }^{38}$

Devair Müfettişliği sırasında dile getirdiği ve kendisini meşgul eden konulardan biri de Rumeli'nin durumu, Rumeli muhacirlerinin yaşadı ğı sıkıntılar ve alınması gereken tedbirler ile onların öksüz ve yetim çocuklarının durumu ve eğitimleridir. Herşeyden önce Rumeli'deki Müslüman halkın göç etmeyip, yerlerinde kalmaları gerektiğini savunmakta, Rumeli'nin Osmanlı Devleti’nin elinde kalmasının devletin varlığını sürdürmede sonderece önemli olduğuna inanmaktadır. Bunu her vesilede dile getirmiş ve bununla ilgili görevlendirildiği her platformda bunu savunmuş ve bunun için çeşitli çözüm önerilerinde bulunmuştur. Ancak bu gerçekleşmeyip kitleler halinde Trakya ve İstanbul'a göçler başlayınca, gerek muhacirlerin sorunları gerekse onlardan kaynaklı çeșitli problemlerle yakından alakadar olmuștur. Her iki konuya da yüzeysel bakmamış, gerek uzun gerekse kısa vadede nelerin yapılması gerektiği ile

\footnotetext{
${ }^{35}$ BOA, YEE 44 / 138. 11 Mart 1881 (10 Rebiülahir 1298) tarihli Safvet Paşa'nın yazısı.

${ }^{36}$ İlhan Tekeli - Selim İlkin, Osmanlı İmparatorluğu'nda Ĕgitim ve Bilgi Üretim Sisteminin Oluşumu ve Dönüşümü, Ankara 1993, s. 67.

${ }^{37}$ İ. Hakkı Uzunçarşıllı, "Merhum Sadullah Paşa'nın Safvet ve Cevdet Paşalar ve Safvet Paşazade Refet Beyle Mektuplaşması", Belleten, Cilt: XV. Sayı: 58, TTK, Ankara 1951, s. 263.

${ }^{38}$ BOA, YEE 78 / 48 / 138. 19 Ocak 1881 (17 Safer 1298) tarihli Safvet Paşa'nın yazısı.
} 
ilgili görüşlerini dile getirmiştir. Uzun vadede bilhassa muhacir çocuklarının eğitimlerinin son derece önemli olduğu düşüncesindedir. Çünkü eğer bu çocuklar eğitilip bir meslek sahibi yapılmazsa ileride toplum için daha büyük problemlere sebep olabileceklerdir. Bu çocuklara bir meslek edindirmek amacıyla bir sanayi mektebinin kurulması için çalışmalarda bulunmuştur.

\section{Kaynakça}

\section{Başbakanlık Osmanlı Arşivi}

Dahiliye Nezareti İdare Evrakı

Yildız Esas Evrak

\section{Tetkik Eserler ve Makaleler}

ARAZ, Yahya, 16. Yüzyıldan 19. Yüzyıl Başlarına Osmanlı Toplumunda Çocuk Olmak, Kitap Yayınevi, İstanbul 2013.

AYHAN Halis - MAVIŞ̧ Hakkı, "Darüşşafaka", Türkiye Diyanet Vakfi İslam Ansiklopedisi, İstanbul 1994, Cilt: IX, s. 7-9.

ERGIN, Osman, Türk Maarif Tarihi, Cilt: I-II, İstanbul 1977.

İNAL, İbnü'l-Emin Mahmud Kemal, Osmanlı Devrinde Son Sadrazamlar, C. VI, İstanbul 1955.

İPEK, Nedim, Rumeli'den Anadolu'ya Türk Göçleri (1877-1890), Ankara 1994.

İSKENDER, Pelin, Mehmed Esad Safvet Paşa (1814-1883 / H. 1230-1301), Ondokuz Mayıs Üniversitesi Sosyal Bilimler Enstitüsü Tarih Anabilim Dalı, Yayımlanmamış DoktoraTezi, Samsun 1999.

KOCACIK, Faruk, "Balkanlar'dan Anadolu'ya Yönelik Göçler (1878-1890)”, Osmanlı Araştırmaları, Sayı:1, İstanbul 1980, s. 137-190.

KODAMAN, Bayram, Abdülhamid Devri Eğitim Sistemi, TTK Basımevi, Ankara 1991.

KURT, Burcu, "Modernleşen Sanayiye Ayak Uydurmak: Osmanlı Irak'inda Kurulan Sanayi Mektepleri", History Studies, Volume 5, Issue 3, Mayıs 2013, s. 151-153.

ÖZBEK, Nadir, Osmanlı İmparatorluğu'nda Sosyal Devlet Siyaset, İktidar ve Meşruiyet 1876-1914, İletişim Yayınları, İstanbul 2013.

ŞAFAK, Nurdan, "Osmanlı İmparatorluğu'da Kimsesiz Çocuk Olmak ve Islahhaneler (1863-1903)", Osmanlı Dünyasında Çocuk Olmak, Ed. Haşim Şahin-Nurdan Şafak, Dem Yayınları, İstanbul 2012, s. 131-163.

ŞİMŞİR, N. Bilal, "Bulgaristan Türkleri ve Göç Sorunu”, Bulgaristan'da Türk Varlı̆̆ı-I, Ankara 1987, s. 47-66. , Rumeli'den Türk Göçleri, Cilt: II, Ankara 1989.

TEKELİ, İlhan, “Tanzimat'tan Cumhuriyet'e Eğitim Sistemindeki Değişmeler”, Tanzimat'tan Cumhuriyet'e Türkiye Ansiklopedisi, İletişim Yayınları, Cilt: II, İstanbul 1985, s. 456-475.

TEKELİ, İlhan - İLKİN, Selim, Osmanlı İmparatorluğu'nda Eğitim ve Bilgi Üretim Sisteminin Oluşumu ve Dönüşümü, Ankara 1993. 
TEMİZR, Abidin, “Karadağ'da Öteki Sorunu: Müslümanlar (1878-1913)”, History Studies, Volume 5, İssue 3, Mayıs 2013, s. 223-240.

UZUNÇARŞILI, İ. Hakkı, "Merhum Sadullah Paşa'nın Safvet ve Cevdet Paşalar ve Safvet Paşazade Refet Beyle Mektuplaşması", Belleten, Cilt: XV. Sayı: 58, TTK, Ankara 1951, s. 263-299.

ÜNLÜ, Mucize, "II. Abdülhamid Döneminde Balkanlarda Fakir ve Kimsesiz Çocuklar", Geçmişten Günümüze Şehir ve Çocuk, Editör: Osman Köse, Canik Belediyesi Kültür Yayınları, Samsun 2016, s. 809-818. 